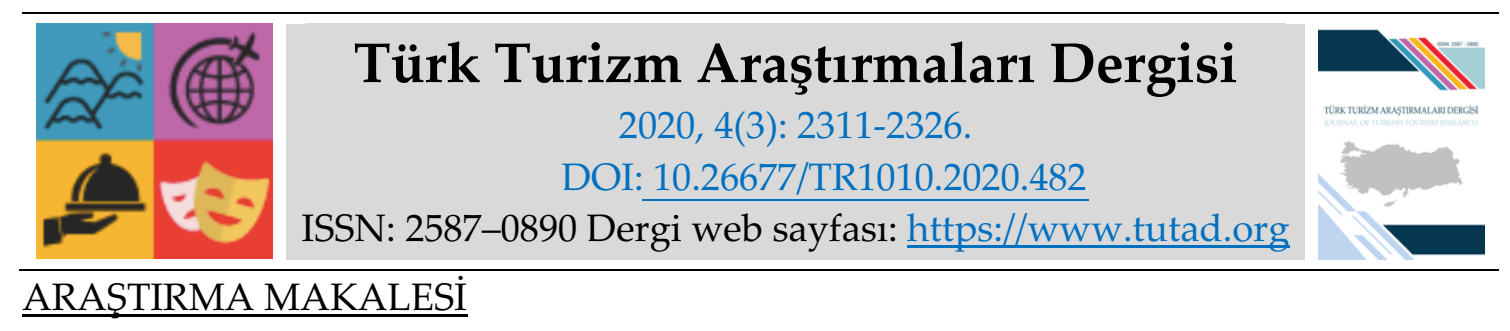

\title{
Turizm Öğrencilerinin Sayısal Derslerdeki Başarısızlık Nedenlerinin Nitel Araştırma Yaklaşımıyla Belirlenmesi ve Çözüm Önerileri
}

Doç. Dr. V. Uğur TANDOĞAN, Aydın Adnan Menderes Üniversitesi, Turizm Fakültesi, Aydın, e-posta: ugutan@yahoo.com

ORCID: https://orcid.org/0000-0001-5392-6147

Aziz Batuhan DİNÇEL, Yüksek Lisans Öğrencisi, Aydın Adnan Menderes Üniversitesi, Sosyal Bilimler Enstitüsü, Aydın, e-posta: batudncl@gmail.com

ORCID: https://orcid.org/0000-0002-0768-3583

Öz

Bu çalışmanın amacı turizm öğrencilerinin lisans düzeyinde aldığı bir takım sayısal derslerdeki başarısızlık nedenlerini ortaya çıkartmaktır. Bu amaç doğrultusunda çalışma nitel araştırma yöntemleriyle gerçekleştirilerek Adnan Menderes Üniversitesi Turizm Fakültesindeki öğrenci ve öğretim üyeleriyle görüşmeler yapılmıştır. Çalışmanın bulgularına göre sayısal derslerde başarısız olma durumunun öğrencilere göre fiziksel ve davranışsal nedenlerden dolayı olduğu anlaşılmıştır. Ancak bulguların en dikkat çekici tarafıysa öğretim üyelerine göre öğrencilerin sayısal derslerde başarısız olmasındaki en etkili sebebin yine öğrencilerin davranışsal nedenleriyle alakalı olması ve fiziksel nedenleri başarısızlığa bahane olarak göstermeleridir. Çalışmanın sonucunda turizm öğrencilerinin sayısal derslerdeki başarısızlıklarına sebep olarak gösterilen birtakım nedenlere ulaşılarak literatürdeki benzer çalışmalarla karşılaştırılmıştır. Son olarak turizm öğrencilerinin sayısal derslerdeki başarılarını artırmaya yönelik önerilerde bulunulmuştur.

Anahtar Kelimeler: Sayısal Dersler, Akademik Başarısızlık, Nitel Araştırma Yöntemleri, Turizm. Makale Gönderme Tarihi: 04.04.2020

Makale Kabul Tarihi: 03.07.2020

\section{Önerilen Atıf:}

Tandoğan, V. U. ve Dinçel, A. B. (2020). Turizm Öğrencilerinin Sayısal Derslerdeki Başarısızlık Nedenlerinin Nitel Araştırma Yaklaşımıyla Belirlenmesi ve Çözüm Önerileri, Türk Turizm Araştırmaları Dergisi, 4(3): 2311-2326.

(C) 2020 Türk Turizm Araştırmaları Dergisi. 


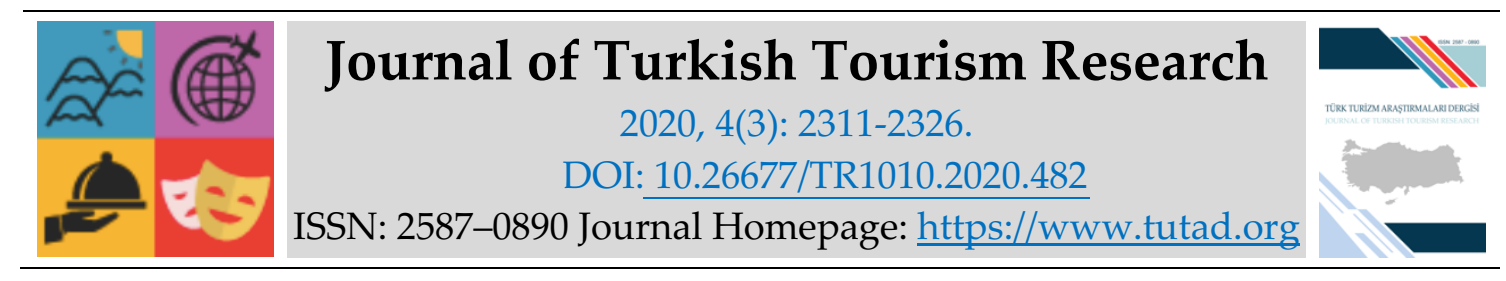

\title{
$\underline{\text { RESEARCH PAPER }}$
}

\section{Determining Failure Problems of Tourism Students in Numerical Courses with the Qualitative Approach and Solution}

Associate Prof. Dr. V. Uğur TANDOĞAN, Aydın Adnan Menderes University, Faculty of Tourism, Aydın, e-mail: ugutan@yahoo.com

ORCID: https://orcid.org/0000-0001-5392-6147

Aziz Batuhan DİNÇEL, MSc., Aydın Adnan Menderes University, Social Sciences Institute, Aydın, e-mail: batudncl@gmail.com

ORCID: https://orcid.org/0000-0002-0768-3583

\begin{abstract}
The aim of this study is to reveal the reasons for the failure of tourism students in numerical courses taken at the undergraduate level. For this purpose, the study was carried out with qualitative research methods and interviews were held with students and faculty members at Adnan Menderes University Tourism Faculty. According to the findings of the study, it was understood that the failure in numerical courses was due to physical and behavioral reasons according to the students. However, the most striking aspect of the findings is that the most effective reason for the students' failure in numerical lessons is that they are related to the behavioral causes of the students and they show the physical reasons as an excuse for failure. As a result of the study, a number of reasons which are shown as the reasons for the failure of tourism students in numerical lessons were reached and compared with similar studies in the literature. Finally, suggestions were made to increase the academic success of tourism students.
\end{abstract}

Keywords: Numerical Courses, Academic Failure, Qualitative Research Methods, Tourism. Received: 04.04.2020

Accepted: 03.07.2020

Suggested Citation:

Tandoğan, V. U. and Dinçel, A. B. (2020). Determining Failure Problems of Tourism Students in Numerical Courses with the Qualitative Approach and Solution, Journal of Turkish Tourism Research, 4(3): 2311-2326.

(C) 2020 Türk Turizm Araştırmaları Dergisi. 


\section{Gíriş}

Turizm işletmeciliği alanında eğitim veren 4 yıllık yükseköğretim kurumlarının temel misyonu, öğrencilerini bir turizm işletmesinin orta ve üst düzey yönetiminde görev alabilecek ya da kendi iş yerini yönetebilecek niteliklerle donatmaktır. Bir işletmenin üst yöneticisi olmak; işletmenin rakiplerine ve hedeflerine göre mevcut durumunun ne olduğunu, faaliyetlerinin nasıl yürüdügünü, faaliyetler sırasında ortaya çıkan sorunların neler olduğunu, bunlar için hangi çözüm önerilerinin uygulanabileceğini, işletmenin güçlü-zayıf yanlarını ve gereksinimlerini iyi anlamayı ve işletmeyi daha geliştirebilmek için doğru kararlar alabilmeyi gerektirir. Bir üst düzey yönetici, işletmesini ne kadar iyi anlayabilirse, onu o kadar iyi yönetebilir. İşletmeler, üst düzey yöneticileri ile sayısal veriler sayesinde iletişim kurabilirler. Başka bir ifade ile bir yöneticinin işletmeyi anlaması işletme faaliyetlerince oluşan sayısal verileri doğru okuyabilmesine bağlıdır. Bunu yapabilmeleri için işletmenin en küçükten en büyüğe kadar bütün faaliyetleri sayısal olarak muhasebe sistemine kaydedilir ve düzenlenerek yöneticilere raporlanır. Finansal raporlar olarak adlandırılan bu bilgiler, üst yöneticilerin sayısal analizler yaparak işletmeyi hızla anlamasına ve geç olmadan doğru kararlar almasına yardımcı olmaktadır.

Turizm alanındaki işletme bölümleri yönetime yönelik eğitimlerin verilmesinden dolayı içeriğinde belli başlı sayısal dersler bulunmaktadır. Zaten ülkemizde yükseköğrenime geçiş sisteminde işletme bölümlerinin öğrenci kabulü eşit ağırlık (Türkçe-Matematik) notuyla yapılmaktadır. $\mathrm{Bu}$ uygulamada öğrencilerin alacakları sayısal derslerin bir ön koşulu niteliğindedir. Sonuç olarak öğrencilerin akademik alanda başarılı olmaları öncelikle kendi gelecek planları ve kariyerleri açısından daha sonra turizm endüstrisine nitelikli personel ve bilgi birikimi sağlaması bakımından büyük önem taşımaktadır.

Akademik başarı, öğrencilerin aldıkları eğitim doğrultusunda beklenen davranış değişikliklerini kazanma düzeyi şeklinde ifade edilebilir (Güllüeroğlu, 2005; Taşlıyan vd., 2014). Turizm eğitimi, topluma turizm bilincini kazandırmak, endüstriye yönelik temel prensiplerin öğretilmesini sağlamak, turizm endüstrisinde çalışacak personeli endüstri gereksinimleri doğrultusunda genel, mesleki ve teknik bilgilerle yetiştirmek için yapılan faaliyetlerdir (Çimen, 2006; Olcay, 2008). Turizm 19. yüzyılın başlarında coğrafya, sosyoloji ve ekonomi gibi bilim dallarının içerisinde incelenirken 20. yüzyılda diğer bilim dallarından ayrı olarak incelenmeye başlanmıştır (Echtner ve Jamal, 1997).

Günümüzde turizm yüksek öğretimi düzeyinde; konaklama işletmeciliği, seyahat işletmeciliği, yiyecek içecek işletmeciliği, turizm rehberliği, gastronomi, rekreasyon yönetimi gibi birçok bölüm mevcuttur. Bu çalışmada örnek kapsamına alınan Adnan Menderes Üniversitesi Turizm Fakültesinin işletme yönetimi gerektiren bölümlerinde muhasebe, maliyet analizi, finansal yönetim gibi sayısal dersler bulunmaktadır. Muhasebe derslerinde işletme faaliyetlerinin muhasebe sistemine nasıl kaydedildiği ve nasıl raporlandığı, turizm işletmelerinde gerçekleşen başlıca faaliyetlerin kayıtları öğretilmektedir. Maliyet Analizi derslerinde üretim ve hizmet işletmelerinde gider ve maliyetin nasıl oluştuğu, gider ve maliyet türleri, kar planlaması ve stok maliyetleme yöntemleri anlatılarak bir işletmenin maliyetlerindeki özelliklere göre bunları nasıl kontrol edeceği öğretilmektedir. Finansal Yönetim derslerinde ise muhasebe fonksiyonunun hazırladığı finansal raporlardan yararlanarak işletmenin piyasaya, rakiplere ve geçmişine göre performansının ne olduğu, üstün ve zayıf yönlerin belirlenmesi, olası finansman sorunları ve alınabilecek önlemler, finansman ve yatırım kararları ile birlikte piyasadaki ekonomik verilerin değerlendirilmesi gibi bilgiler öğretilmektedir.

$\mathrm{Bu}$ çalışmanın amacı, turizm öğrencilerinin sayısal derslerdeki başarısızlık nedenlerini ortaya çıkartmaktır. Başarısızlık nedenlerinin belirlenmesi gerek öğrenci tarafında gerekse eğitim veren kurum ve dersin hocası tarafında düzenleme ve iyileştirmelerin yapılabilmesine imkân 
sağlayacağından önemlidir. Böylece hem eğitim veren hem de alan tarafta iyileştirmenin olması, eğitim kurumunun çıktısı olarak görülen mezun turizm öğrencilerinin akademik başarılarının yükseltilmesinde, kariyer olanaklarının arttırılmasında etkili olacaktır. Bunun sonucunda daha nitelikli yönetici, girişimci ve akademisyen adaylarının yetişmesi mümkün olacağından çalışma turizm endüstrisi için de önem taşımaktadır. Ayrıca, literatürde okullardaki sayısal ders başarısını inceleyen araştırmaların genel olarak nicel yöntemlerle yapıldığı görülmekteyken, bu çalışmada nitel araştırma yöntemi kullanılmıştır. Bu nedenle çalışma, sayısal başarıyı inceleyen araştırmalar içerisinde yöntem açısından da ender bir çalışma olma özelliği taşımaktadır.

\section{KAVRAMSAL ÇERÇEVE}

Literatür incelendiğinde, öğrencilerin sayısal akademik başarısızlık nedenlerine yönelik pek çok çalışma olduğu görülmektedir. Bu çalışmalarda başarı durumu hem öğretim düzeylerine (liseüniversite) hem de bölümlere (turizm, sağlık, elektrik vb.) göre matematik veya muhasebe gibi farklı sayısal derslerle ve kriterlerle ölçülmektedir. Bu çalışmada turizm bölümü öğrencilerinin sayısal derslerdeki başarısızlık nedenleri, muhasebe ve finansman gurubu dersleri üzerinden incelenmiştir. Tüm sayısal derslerin temelini oluşturan kuşkusuz matematiktir. Bu nedenle literatür incelemesinde; matematik ve muhasebe-finansman derslerindeki başarısızlık durumunu araştıran çalışmalar dikkate alınmıştır.

Karesioğlu ve Duman (2011), meslek yüksekokullarının muhasebe bölümlerindeki eğitim kalitesi üzerine yaptıkları çalışmada bu eğitimin çok yönlü olarak ele alınması gerektiğini belirtmişlerdir. Bu kapsamda kurum yönetiminden öğretim elemanına, teknolojik gelişmelerin takibinden öğrencinin sorumluluğu ve meslek motivasyonuna kadar birçok konuda mevcut durumun izlenmesi ve iyileştirmelerin yapılması önerilmektedir.

İşletme programı olan yükseköğrenim bölümlerinde ve meslek liselerinde sayısal derslere karşı genel bir başarısızlık durumunun varlığı göze çarpmaktadır. Örneğin Kuşat'ın (2014) çalışmasında meslek yüksekokulunda muhasebe eğitimi alan öğrencilerin bu dersten \%62 oranında, sözel bir ders olarak alınan ekonomiden ise \%80 oranında başarılı oldukları belirtilmiştir.

Dursun ve Dede (2004), literatürdeki bazı çalışmaları derleyerek öğrencilerin matematik başarısını etkileyen faktörleri 10 madde altında toplamıştır. Bunlar; cinsiyet, ebeveynlerin eğitim düzeyi, sosyo-ekonomik düzey, öğretmen yeterlilikleri, uygulanan öğretim stratejileri ve teknikleri, okulun fiziksel olanakları, müfredat programı, çok ve disiplinli çalışma, dersi iyi dinleme, matematiksel zeka gibi faktörlerdir. Matematik öğretmenlerinden alınan bilgiler sonucunda, yukarıda sayılan faktörlerden en önemlisinin dersi iyi dinleme; en önemsiz faktörün ise cinsiyet olduğu ortaya konmuştur. Erol ve Erkan da (2008), lisans düzeyinde muhasebe eğitimi alan öğrencilerin başarılarını etkileyen faktörler olarak; sınıftaki fiziki şartları ve öğretim elemanının dersi işleme şeklini belirlemiştir. Thomson vd. (2010), lise öğrencilerinin matematik başarısını etkileyen faktörleri incelemişlerdir. Çalışma sonuçları dört faktör gurubunda toplanmıştır. Bu faktörler sırasıyla; tutum ve yetenek, öğrenci alt yapısı; sınıflar ve öğretmendir. Tutum ve yetenek; öğrencinin sözel yeteneği, derse hazırlanma düzeyi ve derse verilen önem matematik ve fen derslerinde başarıyı artırmaktadır. Öğrenci alt yapısı; yetersiz sosyo-ekonomik alt yapı ve zayıf sözel yetenek matematik başarısını düşürmektedir. Matematik başarısında cinsiyet etkisi çok küçük olmakla beraber erkek öğrenciler biraz daha başarılı görünmektedir. Sınıflar; sınıfta sosyal alt yapısı ve yetenek düzeyi yüksek olan öğrencilerin olması sınıfın matematik başarısını yükseltmektedir. Öğretmen; küçük sınıflarda sayısal derslerde öğretmen cinsiyeti fark yaratmakta ve erkek öğretmenin matematik başarısının öğrenciler üzerinde daha 
etkili olduğu, büyük sinıflarda ise cinsiyet yerine öğretmen tecrübesinin daha etkili olduğu görülmektedir.

Yapılan çalışmalar, öğrencinin muhasebe gibi bir dersi meslek hayatı için yararlı görmesinin ve başarı konusunda kendisine güvenmesinin ders başarısını etkileyen önemli bir faktör olduğunu göstermektedir. Tho (2007) çalışmasında, öğrencilerin kendilerini başarı için yeterli düzeyde görmelerinin başarıyı arttırdığı sonucuna varmıştır. Bernardi ve Bean (2002), muhasebenin mesleki hayatta sağlayacağ fayda ile ilgili öğrenciyi bilgilendirmenin motivasyonu artırdığını, bunun da muhasebe ders başarısını olumlu yönde etkilediğini belirlemiştir. Çoşgun (2013)'un çalışmasında da benzer sonuçlar görülmektedir. Muhasebe bölümü öğrencilerinin meslek hayatıyla ilgili beklenti ve motivasyonlarının yüksek olması, muhasebe eğitimine olan ilgiyi ve sonucunda başarıyı artırmaktadır.

Öğrencinin eğitim gördüğü bölümü seçmesindeki temel neden veya beklenti onun derslere olan motivasyonunu etkileyebilmektedir. Örneğin öğrencinin meslek lisesi eğitimini gelecekteki mesleği olarak değil de başka bir amaç için atlama tahtası olarak görmesi, ders programında yer alan ve düzenli çalışma gerektiren matematik dersi ile de gerektiği gibi ilgilenmemesine neden olmaktadır. Mumcu vd., (2012)'nin çalışmasında öğrenciler, meslek lisesini seçmelerinin temel nedeni olarak; gelecekte bu mesleği yapmak yerine meslek lisesi kontenjanını kullanarak yükseköğretime daha kolay geçebilmeyi göstermişlerdir. Aynı öğrencilerin matematik derslerinden başarısız oldukları görülmüştür.

Eğitim gördüğü bölümü seçmedeki temel nedenle ilgili bir başka örnek Sugahara ve Boland (2014)'ın çalışmasında mevcuttur. Japonya'da muhasebe eğitimi veren okullarda lisansüstü öğrencilerine yönelik yapılan bu çalı̧̧mada; öğrencilerin çoğunun hedefinin, yeminli mali müşavir veya vergi uzmanı sınavlarını geçebilmek olması beklenirken sonuç farklı çıkmıştır. Öğrencilerin çoğu, kişisel gelişim ve çevre edinmek için bu programda bulunduklarını ifade etmişlerdir. Öğrenciler ayrıca, muhasebe ders başarısında en etkili faktör olarak öğretim elemanı değil; onun yerine öğrencideki öz denetimin, ders çalışmadaki sürekliliğin ve ders öncesi ve sonrası yapılan çalışmaların etkili olduğunu belirtmişlerdir.

Karcıoğlu vd.'nin (2010), lisans düzeyinde muhasebe eğitimi gören öğrenciler üzerine yaptığ çalışma sonuçlarına göre; yeniliklere açık, sorumluluk bilinci yüksek, dışa dönük ve uyumlu olma özelliklerine sahip öğrencilerin muhasebe mesleğine daha yatkın olduğu belirlenmiştir.

Baştürk (2012), öğrencilerin matematik dersindeki başarı ya da başarısızlık nedenlerini belirlemek üzere öğretmenlerin görüşlerini incelemiştir. Çalışmanın bulgularına göre; öğrencinin önceki sınıflarda alması gereken temel bilgilerde eksikliklerin olması, ders çalışma yöntemlerinin bilinmemesi, evde çalışma ortamının ve bilgisayarın olmaması, teste dayalı sınavların olması ve derse ayrılan sürenin yetersizliği en önemli nedenler olarak belirlenmiştir.

Demir ve Çam (2006), çalışmalarında muhasebe yükseköğrenimi gören öğrencilerin başarısızlık nedenlerini öğrencilere sorarak incelemiş, en önemli başarısızlık nedeni olarak; muhasebe derslerinin öğrencide belli bir bilgi temeli olduğu varsayılarak işlenmesi gösterilmiştir. Verilen cevaplardan, derslere devamsızlığın başarısızlık nedeni olarak görülmediği de ortaya çıkmıştır. Oysa Jameel ve Hamdan (2015) yapmış oldukları çalışmalarında derse katılım düzeyi yüksek olan üniversite öğrencilerinin muhasebe başarılarının da yüksek olduğunu belirlemişlerdir.

Özdemir vd. (2018), öğrencilerin muhasebe-matematik ilişkisini ve akademik başarılarına olan etkilerini incelemişlerdir. Çalışmaya göre aslında muhasebe sistemini öğrenebilmek için dört işlemden daha ileri düzeyde matematik bilgisine gerek olmadığı, buna karşın mantıksal ilişkileri anlamanın önemli olduğu belirtilmektedir. Ancak, öğrencinin muhasebe dersi üzerindeki yanlış bilgi ve önyargısının muhasebe dersi başarısızlığını -haksız yere- matematik bilgi düzeyine 
yüklediği ifade edilmektedir. Yapılan uygulamada, öğrencilerin çoğunluğu muhasebe eğitiminde ileri düzeyde matematik bilgisi gerektirdiğini belirtmişlerdir. Bu durum da öğrenci üzerinde gereksiz bir kaygı, olumsuz bir önyargı ve sonucunda başarısızlık oluşturmaktadır. Gerçekten de öğrenciler, muhasebe dersindeki başarısızlıklarının nedeni olarak matematik bilgilerindeki eksikliği göstermişlerdir.

İlhan ve Sünkür (2013), matematik başarısını etkileyen bir faktör olarak matematik kaygısının öğrencilerin cinsiyet ve sınıfları bakımından incelemişlerdir. Çalışma sonuçlarına göre öğrencilerin sınıfları ilerledikçe matematiğe duyulan kaygı, matematik başarısı üzerinde daha fazla etkili olmaktadır.

Baard vd. (2010), Güney Afrika'da muhasebe eğitimi alan birinci sınıf öğrencilerinin başarılarını etkileyen faktörleri incelemiştir. Başarı ölçütü olarak alınan faktörlere göre sonuçlar şöyle belirlenmiştir: Sınıf ortalamasına göre başarı notu yüksek olanlar, kız öğrenciler, orta öğrenimde muhasebe dersi almış olanlar, orta öğretimde muhasebe, matematik ve fen ders notları yüksek olanlar, derse devamlılığı olanlar ve dersin verildiği dilde ana dile sahip olanlar muhasebe derslerinde daha başarılı olmuşlardır.

Koh ve Koh (1999), Singapur'da üniversite düzeyinde üç yıllık muhasebe eğitimi alan öğrencilerin performanslarını etkileyen faktörler üzerine bir araştırma yapmıştır. Başarı ölçütü olarak alınan faktörlere göre sonuçlar şöyle belirlenmiştir: Erkek öğrenciler, önceden iş tecrübesi olanlar, akademik ve matematik başarısı daha yüksek olanlar, muhasebe programında daha başarılı olmaktadırlar. Bununla beraber öngörülerin aksine, orta öğretimde muhasebe dersi almış olan öğrenciler, bu dersi almamış olanlardan daha kötü bir performans sergilemişlerdir. Benzer bir sonuç Karcıoğlu vd.'nin (2016) yaptığı çalışmada ortaya çıkmıştır. Açık öğretim fakültesinde lisans ve ön lisans düzeyinde muhasebe eğitimi alan öğrencilerin başarısı incelenmiştir. Sonuçlara göre ticaret lisesi mezunu öğrencileri, muhasebe derslerinde normal lise mezunu öğrencilerden daha düşük performans göstermişlerdir.

\section{YÖNTEM}

Adnan Menderes Üniversitesi Turizm Fakültesi'nde konaklama, seyahat, yiyecek içecek işletmecilikleri ve rehberlik olmak üzere dört bölüm bulunmaktadır. Sayısal dersleri bulunmadığından rehberlik bölümü öğrencileri bu çalışmanın dışında bırakılmıştır. Çalışmanın ana kütlesi okul idaresinden alınan 2017-2018 akademik yılı öğrenci sayılarına göre konaklama işletmeciliği (848), seyahat işletmeciliği (444) ve yiyecek içecek işletmeciliği (544) bölümleri toplamda 1836 öğrenci olarak belirlenmiştir.

Akademik başarı ölçütü için öğrencilerin muhasebe, maliyet analizi ve finansal yönetim derslerinden aldıkları geçme notlarının ortalamaları kullanılmıştır. Elde edilen verilere göre öğrencilerin \%63'ünün sayısal ders niteliği taşıyan muhasebe, maliyet analizi ve finansal yönetim derslerinden başarısız oldukları tespit edilmiştir (Tablo 1).

\section{Formül:}

$$
\text { Başarı oranı }=\frac{\text { Başarılı Öğrenciler }}{\text { Sinava Giren Öğgrenciler }}
$$

\section{Formül:}

Ağırlıklı Ortalama Başarısızlık Oranı =

1 - (Ağırlıklı Ortalama Başarı Oranı) 
Tablo1: 2017-2018 Güz Dönemi Tüm Sayısal Derslerin Sınava Giren Öğrencilere Göre Başarı/Başarısızlık Durumu

\begin{tabular}{|c|c|c|c|}
\hline Öğrenci Sayısı & Ağırlık & Başarı Oranı & Ağırlıklı Başarı Oranı \\
\hline 68 & $\% 8,6$ & 0,22 & 0,019 \\
\hline 68 & $\% 8,6$ & 0,19 & 0,016 \\
\hline 127 & $\% 16$ & 0,15 & 0,024 \\
\hline 127 & $\% 16$ & 0,15 & 0,024 \\
\hline 9 & $\% 1,1$ & 0,22 & 0,002 \\
\hline 44 & $\% 5,6$ & 0,55 & 0,031 \\
\hline 50 & $\% 6,3$ & 0,46 & 0,029 \\
\hline 68 & $\% 8,6$ & 0,54 & 0,046 \\
\hline 68 & $\% 8,6$ & 0,57 & 0,049 \\
\hline 68 & $\% 8,6$ & 0,72 & 0,062 \\
\hline 93 & $\% 12$ & 0,56 & 0,067 \\
\hline Toplam $=790$ & Toplam $=\% 100$ & \multicolumn{2}{|c|}{ Ağırlıklı Ortalama Başarı Oranı =0,37 } \\
\hline & & \multicolumn{2}{|c|}{ Ağırlıklı Ortalama Başarısızlık Oranı =0,63 } \\
\hline
\end{tabular}

Literatürden de anlaşıldığı üzere başarısızlı̆̆ı etkileyen pek çok faktör bulunmaktadır. Akademik başarısızlığa öğrencilerin çeşitli durum ve davranışlarının doğrudan veya dolaylı olarak ilişkisi olduğu ortadadır. Türnüklü (2000)'e göre bireylerin davranışlarının nedeninin veya bir konuya yönelik duygu ve düşüncelerinin derinlemesine öğrenebilmenin en uygun yolu söz konusu kişiyle görüşmektir. Bu çalışmada öğrencilerin sayısal derslerdeki başarısızlık nedenlerini ortaya koymak için nitel araştırma yöntemlerinden görüşme tekniğine karar verilmiştir. Bu doğrultuda akademik başarısızlığa taraf olabilecek öğrencilerle odak grup görüşmesi ve öğrencilerin sayısal derslerini aldıkları iki öğretim üyesiyle de yarı yapılandırılmış görüşme gerçekleştirilmiştir. Bazı bireylerin yüz yüze etkileşimi korkutucu bulmasından dolayı odak grup görüşmeleri bu tür katılımcılara da erişebilmeyi sağlamaktadır (Morgan, 1997). Bugüne kadar yapılmış olan odak grup çalışmalarında örneklem büyüklügü hakkında kesin bir sayı verilmemiştir. Ancak nitel araştırma yöntemlerinde ortak bir görüş olarak amaçlı ve gönüllü örneklemeden bir de veri doygunluğundan söz edilmektedir. Gönüllü örneklemede katılımcılar araştırmaya ilan ve davet yoluyla belirlenirken araştırmacı bu ilan ve davette belirli özellikler de belirtebilir (Başkale, 2016). Diğer yandan örneklem, farklı görüşler elde edilebilecek kadar büyük ancak her katılımcının görüşlerini ifade edebileceği kadar az olmalıdır. Böylece 3-5 odak grup, veri doygunluğuna ulaşabilmek için yeterli olmaktadır (Holloway ve Wheeler, 1996; Onwuegbuzie ve Leech, 2007). Görüşmenin ne zaman ve nerede yapılacağı, katılımcıların nasıl seçileceği, moderatörlüğü kimin yapacağı, katılımcılara sorulacak soruların neler olacağı konusunda detaylı bir plan yapılmıştır. Çalışmada katılımcılar gönüllü örnekleme yöntemi ile belirlenmiştir. Bu tür görüşmelerde gönüllü ve istekli katılımcıların bulunması araştırmalardaki gönülsüz katılımların engellenmesini sağlamaktadır (Morgan, 1997). Konaklama işletmeciliği, seyahat işletmeciliği ve yiyecek içecek işletmeciliği bölümlerinin her birinin aldıkları sayısal derslerin farklı olmasından dolayı her bölüm için ayrı odak gruplar tasarlanmıştır. Araştırma, çalışmanın gerçekleştirildiği dönemde stajda olmayan ve sayısal derslerin tamamını almış olan sınıflarla sınırlıdır. Bu kriterler doğrultusunda odak grupların oluşturulması için her bölümden 20 öğrenci mail ve telefon aracılığıyla davet edilmiştir. Daveti kabul eden katılımcılara görüşmenin yeri ve zamanı bir hafta önceden bildirilmiştir. Görüşme okulun çok amaçlı salonlarından birinde gerçekleştirilmiş ve oturma düzeni U şeklinde hazırlanmıştır. Oturma düzeninin şekli katılımcıların görüşme esnasında birbirleriyle daha rahat etkileşim kurmaları açısından bu şekilde ayarlanmıştır. Çünkü 
odak grup çalışmalarında yuvarlak masa toplantı düzeni veya $U$ düzeninin tercihi odak grubun daha etkin olmasını sağlamaktır (Suler, 1995; Edmunds, 2000; Çokluk vd., 2011).

Görüşmeler başlamadan önce katılımcılardan kısaca kendilerini tanıtmaları istenmiştir. Katılımclara araştırma ile ilgili açıklama yapılmış ve görüşmelerin kamera ile kaydedileceği belirtilmiştir. Görüşmeler turizm işletmeciliği bölümünde yüksek lisans yapan ve araştırma yöntemleri, iletişim gibi dersleri görmüş bir moderatör eşliğinde yapılmıştır. Çalışmada yarı yapılandırılmış görüşme tekniği kullanılmıştır. Bu teknik görüşme sorularının önceden belirlenmiş olmasına rağmen görüşme esnasında gerek duyulduğunda önceden planlanmamış ek soruların da sorulabildiği esnek bir yapıya sahiptir (Mil, 2007: 8). Yarı yapılandırılmış görüşmeler, yapılandırılmış görüşmelere göre daha zengin veri elde etmeyi sağlarken, yapılandırılmamış görüşme tekniğine kıyasla daha sistematik ve karşılaştırılabilir bilgi sunmaktadır (Yıldırım ve Şimşek, 1999). Görüşmede konunun dışına çıkılmasının önüne geçmek için gerekli noktalarda katılımcılara önceden hazırlanmış sorular sorulmuştur. Sorulan her soru için katılımcılardan tek tek yanıt alınmış böylelikle hiç konuşmayan katılımcıların görüşmeye dahil edilmesi sağlanmıştır. Karmaşık, anlaşılmayan veya fazla yüzeysel cevaplar veren katılımcılardan ifadelerini açıklamaları istenmiştir. Son olarak katılımcıların konuyla alakalı genel görüşleri alınarak görüşme sonlandırılmıştır. Görüşmeler ortalama 35 dakika sürmüştür. Görüşme kayıtları daha sonra Microsoft Word programıla doküman haline dönüştürülmüştür. Odak grup görüşmelerinden 28, öğretim üyelerinden 3 sayfa olmak üzere toplamda 31 sayfa doküman elde edilmiştir. Elde edilen veriye betimsel analiz uygulanmıştır.

Nitel araştırmalarda sıkça kullanılan veri toplama yöntemi olan görüşme tekniği her ne kadar veri bakımından zengin olsa da araştırmacıların toplanan verilerden farklı sonuçlar elde etme olasılığı vardır. Ulaşılan sonucun gerçeği ne derecede yansıttığının belirlenebilmesi için katılımcılarla oluşturulacak bir teyit mekanizması faydalı olacaktır (Yıldırım ve Şimşek, 2013). Erlandson, Harris, Skipper ve Allen (1993) katılımcı teyidinin veri toplama işleminin hemen ardından yapılabileceği gibi daha geniş zamanda elde edilen verilerin analiz edilerek bir rapor halinde katılımcılara gönderilmesiyle de mümkün olduğunu belirtmişlerdir. Görüşme kayıtları detaylı bir şekilde izlenerek raporlanmıştır. Elde edilen veri, katılımcıların ortak görüşleri dikkate alınarak farklı temalara ayrılmıştır. Katılımcıların belirttiği ifadeler ana fikri değiştirilmeden özetlenmiştir. Bulgular kısmı hazırlandıktan sonra katılımcılara mail yolu ile ulaşılarak, odak grup görüşmesinde ifade ettikleri görüşlerin çalışmada eksiksiz ve doğru şekilde belirtildiğine dair katılımcı teyidi alınmıştır.

\section{BULGULAR}

Uygulama kapsamında odak grup görüşmesi için öğrenciler davet edilmiş ve 15 öğrenci daveti kabul etmiştir. Bu öğrenciler, bölümlerine göre konaklama, seyahat ve yiyecek-içecek bölümü olmak üzere 3 gruba ayrılmış ve her grupla ayrı ayrı odak grup görüşmeleri gerçekleştirilmiştir. Ayrıca sayısal derslere giren iki adet öğretim üyesi ile yarı yapılandırılmış görüşme yapılmıştır.

\section{Konaklama İşletmeciliği}

Konaklama işletmeciliği bölümünün ders programına göre 1 . sinıfta sayısal ders bulunmamaktadır. 4. sınıfta da öğrenciler, uygulama dersi kapsamında işletmelerde staj yapmakta ve dönem boyunca okul dışında bulunmaktadır. Bu nedenle konaklama bölümünden yalnızca 2. ve 3. sınıf öğrencileri görüşmeye davet edilmiştir. Davete bu bölümden 3 erkek ve 2 kız öğrenci olmak üzere 5 kişi katılmıştır. Bu derslerden başarılı veya başarısız olmasına bakılmaksızın tüm öğrenciler karma olarak görüşme grubuna alınmıştır. 
Katılımclar öncelikle derslere olan katılımın çok olduğunu bu yüzden de derslerin okulda bulunan Çok Amaçlı Salon [ÇAS]'da işlendiğini belirtmişlerdir. ÇAS'ın çok büyük bir salon olmasından dolayı ders hocasının sesini sınıfın arkasından duymakta ve tahtadaki yazıları görmekte güçlük çektiklerini belirtmişlerdir. Sınıfların kalabalık olmasından dolayı oluşan gürültünün, derse konsantre olmayı ve konuların anlaşılmasını güçleştirdiğini ifade etmişlerdir. Katılımcılardan bazıları, ders esnasında anlayamadıkları konuları sınıftaki kalabalıktan çekindikleri için soramadıklarını belirtmişlerdir. 2 nolu katılımcı bunun üzerine, hocanın her fırsatta anlamadıkları konuları sormaları için öğrencilere uyarıda bulunduğunu ancak kimsenin soru sormaya yeltenmediğini ifade etmiştir.

Katılımclar sayısal derslerde not tutmanın başarıya katkısı olacağını belirtmişlerdir. Bununla beraber not tutmayla ilgili sayısal derslerde başarısızlığa neden olabilecek iki konuya değinmişlerdir. Bunlardan ilki öğrencilerin büyük çoğunun derslere gelirken not tutmak için gerekli araç gereci getirmemeleridir. Diğer konu ise not tutan öğrencilerin dersin hızına yetişememesi ile ilgilidir. Bazı öğrencilerin not tutmakta yeterince hızlı olamayıp ses ve görüntü kayıtları aldıklarını fakat bundan da yararlanamadıklarını belirtmişlerdir. Bunun nedeni olarak da ders sırasında anlaşılmayan bir konuyu tekrar tekrar dinlemenin bir faydası olmayacağ gösterilmiştir.

Katılımcılar derste işlenen konuların ders dışındaki günlerde tekrar edilmesinin sayısal derslerdeki başarılarına olumlu katkı yapacağını belirtmiş fakat yalnızca katılımcı 2 konuları tekrar ettiğini belirtmiştir. Katılımcı 4 derslerde not tutmamasından dolayı tekrar edemediğini belirtirken katılımcı 3 dersleri geçebilmek için gerekli minimum notu aldığını ve bu notları tekrar etmesi durumunda konuyu daha iyi anlayacağını ifade etmiştir. Katılımcılar başarısızlığın bir diğer nedeni olarak konuları anlamaya çalışmak yerine, çoğu zaman sadece ezberlediklerini ve bu nedenle sınavlarda genellikle başarısız olduklarını ifade etmişlerdir. Katılımcılar sınavlarda soruların açık, net, anlaşılır ve işlenen konularla ilgili olduğunu belirtmişlerdir. Katılımcı 1, sınavlarla ilgili görüşlerini şöyle açıklamıştır: "Derslerde çözülen örneklerin tıpa tıp aynısı sorulmuyor. Öğretilen yöntem ile ilgili soru geliyor. Bu nedenle dersteki örnek soruların çözümünü ezberleyenler yöntemi öğrenmeye çalışmadıkları için soruları yapamıyorlar."

Katılımcılara sayısal derslerin amacı konusundaki görüşleri sorulduğunda, dersten başarılı olan katılımcılar sayısal derslerin işletmecilikle ilgili olduğunu ve gelecekte işlerine yarayacağını belirtmişlerdir. Dersten başarısız olan katılımcılar ise sayısal derslerin gereksiz olduğunu ifade etmişlerdir. $\mathrm{Bu}$ yanıtlardan bazı katılımcıların eğitim aldıkları bölümün misyonunu kavrayamadıkları, bu nedenle sayısal derslerin kendilerine ne fayda sağlayacağını bilmedikleri, dersleri yalnızca mezun olmak için aşılması gereken bir engel olduğunu düşündükleri anlaşılmaktadır. Sayısal derslerin amacını bilen ve başarılı olan katılımcı 1, kendisinin derslere bilinçli olarak ve severek geldiğini ama bazı arkadaşlarının sadece dersi geçmeye yetecek kadar çaba gösterdiğini, bu çabanın da genellikle sınavı geçmeye yeterli olmadığını belirtmiştir.

\section{Seyahat İşletmeciliği}

Seyahat işletmeciliği bölümünün ders programına göre 1 . ve 2 . sınıfta sayısal ders bulunmamaktadır. Bu nedenle seyahat bölümünden yalnızca 3. ve 4.sınıf öğrencileri görüşmeye davet edilmiştir. Davete bu bölümden 5 erkek ve 2 kız öğrenci olmak üzere 7 kişi katılmıştır. Bu derslerden başarılı veya başarısız olmasına bakılmaksızın tüm öğrenciler karma olarak görüşme grubuna alınmiştır.

Görüşme sonucunda, 4 katılımcı öncelikle devamsızlığın başarıyı olumsuz etkilediğini belirtmişlerdir. Sayısal derslerde konuların birbirlerini tamamlayan bir bütün olduğunu, konu 
eksiği olduğunda bu eksiği tamamlamanın zor olduğunu ifade etmişlerdir. Katılımcı 1 ise dersin amacının ne olduğunu bilmenin başarı üzerinde önemli bir etkisi olduğunu vurgulamıştır. Ayrıca, dersin amacının farkında olan ve öğrenmek için derse gelen öğrencilerin sıkı bir şekilde not tuttuklarını ancak bu öğrencilerin de sayısının az olduğunu belirtmiştir. Sayısal derslerin amacı ile ilgili, birçok katılımcı derslerin gereksiz olduğunu ve bilgilerin gelecekte yararlı olmayacağını belirtirken sadece katılımcı 2, okudukları bölümün turizm işletmeciliği olduğunu bu nedenle sayısal derslerin işletme bölümleri için temel derslerden olduğunu ifade etmiştir.

Katılımcılar ÇAS'da işlenen derslerin çok kalabalık olduğunu ve yalnızca ön sıralarda oturduklarında dersi dinleyebildiklerini belirtmişlerdir. Derste işlenen konuların daha sonra tekrar edilmesiyle ilgili olarak 6 katılımcı tekrar yapmadığını yalnızca 1 katılımcı işlenen konuları tekrar ettiğini belirtmiştir. Tekrar yapmayan katılımcı 7, her gün uzun süreler tekrar yapılmasa bile kısa süreli ancak düzenli olarak tekrar etmenin başarıya olumlu katkısı olacağını belirtmiştir.

Son olarak katılımcılar, sınavlarda cevapların birbirleri ile bağlantılı uzun işlemlerden oluştuğunu ve işlemlerin sonucunda hata olup olmadığını anlayabildiklerini belirtmişlerdir. 4 katılımcı işlemlerin sonucunda hata yaptıklarını fark ettiklerinde bu hatayı düzeltebilmek için yeterli zamanları olmadığını bu nedenle sınav süresinin yetersiz olduğunu belirtmişlerdir. Bu görüşe karşılık olarak 2 katılımcı, sınav süresinin aynı kalması gerektiğini ve derslere düzenli katılım gösteren öğrenciler için sürenin yeterli olduğunu ifade etmişlerdir.

\section{Yiyecek İçecek İşletmeciliği}

Yiyecek içecek işletmeciliği bölümünün ders programına göre 1. ve 2. sınıfta sayısal ders bulunmamaktadır. Bu nedenle yiyecek içecek bölümünden yalnızca 3. ve 4. sinıf öğrencileri görüşmeye davet edilmiştir. Davete bu bölümden 3 kız öğrenci katılmıştır. Bu derslerden başarılı veya başarısız olmasına bakılmaksızın tüm öğrenciler karma olarak görüşme grubuna alınmıştır.

Katılımcılar sayısal derslerin ÇAS'da işlendiğini belirterek sınıfın arkasında oturanlar için ders hocasının sesini duymakta ve tahtadaki yazıları görmekte güçlük çektiklerini ifade etmişlerdir. Ayrıca salonun kış aylarında yeteri kadar ısıtılmamasından dolayı da derse konsantre olamadıklarını belirtmişlerdir.

Tüm katılımcılar, ders hocasının öğrencilere karşı tutumunun derse devamlılı̆̆a pozitif yönlü bir etki oluşturduğunu belirtmişlerdir. Ayrıca konuların birbirleri ile bağlantılı olmasından dolayı devamsızlığın başarıya etkisi olduğunu ifade etmişlerdir. Katılımcı 2, bir dersi kaçırmanın bile başarıyı etkilediğini ve devam eden konuları da anlamakta sorun yarattığını belirtmiştir.

Katılımcılar derslerde not tutmanın başarıya etkisi olduğunu belirtmişlerdir. Katılımcı 3 ders notlarını öğrencinin kendisinin tutması gerektiğini başka öğrencilerden alınan notların güvenilir gelmediğini ifade etmiştir. Ayrıca katılımcıların tamamı ders esnasında anlayamadıkları konuyu sormadıklarını; öncelikle başkalarının sormasını beklediklerini veya soran olmazsa ders bittikten sonra ders hocasına sorduklarını belirtmişlerdir.

Katılımcların tamamı düzenli olarak not tutmalarına rağmen derste işlenen konuları daha sonra tekrar etmediklerini açıkça ifade etmişlerdir. Dersleri yalnızca sınav öncesi çalıştıklarını, çözüm yöntemini anlamadıkları zaman örnek soru çözümünü ezberleyerek sınava hazırlandıklarını belirtmişlerdir. Katılımcı 1, yalnızca sınavlardan kısa bir süre önce çalıştıkları için konuya hakim olamadıklarını bu nedenle örnek soru çözümlerini ezberleyerek çalıştıklarını, dönem boyunca dersleri düzenli tekrar etmeleri ile konuları daha iyi öğrenebileceklerini ifade etmiştir.

Tüm katılımcılar meslek lisesinden mezun olduklarını bu nedenle lisede yeteri kadar matematik eğitimi almadıklarını belirtmişlerdir. Bundan dolayı sayısal dersleri sevmediklerini ve sayısal 
derslerde ön yargılı olduklarını belirten ifadelerde bulunmuşlardır. Katılımcı 2, sayısal derslerin alt yapısı niteliğinde olan ilkokul ve lise döneminde gördüğü matematik eğitiminde de başarısız olduğunu bu nedenle sayısal derslere karşı ön yargılı ve olumsuz yaklaştı̆̆ını ifade etmiştir.

\section{Öğretim Üyeleri}

Sayısal ders veren iki adet öğretim üyesi ile yapılan yarı yapılandırılmış görüşmede, sözü geçen salonda kış dönemi boyunca sıcaklığın sadece iki veya üç kez düşük olabildiği, dersin bütününü etkileyecek kadar olumsuz şartların oluşmadığı ifade edilmiştir. Nadir de olsa bazı derslerde sınıfların kalabalık olmasının ve öğrencinin kendi arasında konuşmasının dersin kalitesini olumsuz etkilediği belirtilmiştir. Derste anlaşılmayan konuların kendilerine sorulması için öğrencilerin uyarıldığı, soran öğrenciye tekrar anlatıldığı bildirilmiştir. Bunlara ilave olarak, öğrencinin derse olan yanlış bakış açısının ve sayısal kaygısının giderilmesi için derslerin başında öğrenciye bilgi verildiği, derslerin çekiciliğ̈ini artırıcı sınıf içi uygulamalar yapıldığı ifade edilmiştir. Birçok derste öğrencilerin öne oturmak yerine arka sıralara oturmayı tercih ettiği, ya da derse geç kalan öğrencinin mecburen arka sıralara oturmak zorunda kaldığı, bu nedenle tahta görüş mesafesinin uzak olmasının da öğrenciden kaynaklanan bir durum olduğu ifade edilmiştir. Öğretim üyeleri, genel olarak, derslerin öğrenilmesinde ders sürecinden ve sınıfın fiziksel koşullarından kaynaklanan bir sorun olmadığını belirtmişlerdir. Son olarak öğretim üyeleri öğrencilerin sayısal derslerdeki başarılarını arttırmalarına yönelik birtakım önerilerde bulunmuşlardır. Öğretim üyelerine göre sayısal derslerde başarılı olma prensipleri;

- Derslere düzenli olarak katılmak,

- Derslerde not tutmak,

- Derslerde soru çözmek,

- Derste öğretilenleri ezberlemek yerine mantığını kavrayarak anlamaya çalışmak,

- Derste öğretilenleri tekrar etmek şeklinde sıralamışlar ve bu prensipleri sık sık öğrencilere hatırlattıklarını bildirmişlerdir.

\section{TARTIŞMA}

Çalışmanın bulguları toplu olarak incelendiğinde, öğrencilerin sayısal derslerden başarısız olma konusundaki görüşleri şekil 1.'deki gibi iki grupta toplanabilir.

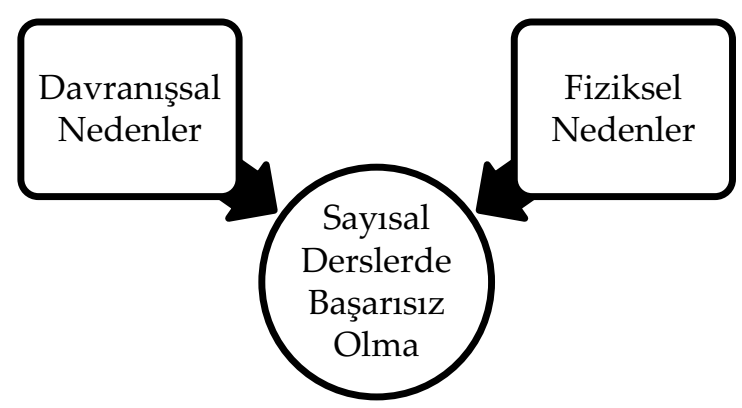

Şekil 1. Öğrenci görüşlerine göre sayısal derslerdeki başarısızlık nedenleri

Öğrencilerle gerçekleştirilen odak grup görüşmelerinden elde edilen bulgulara göre sayısal derslerde başarısız olmaya neden olan fiziksel nedenler; tahtanın görüş mesafesinin uzak, sınıfın ise soğuk, kalabalık ve gürültülü olmasıdır. Literatürde fiziksel nedenlerin sayısal derslerde 
başarısızlığa etki ettiğini gösteren çalışmalar vardır (Dursun ve Dede, 2004; Erol ve Erkan, 2008). Buna karşın, sayısal derslerdeki başarıyı etkileyen faktörler içinde fiziksel nedenlerin ağırlıklı bulunmadığ

Öğrencilerden elde edilen bulgulara göre sayısal derslerde başarısız olmanın diğer nedeni ise davranışsal nedenler olarak gruplandırılabilecek olan; not tutmama, devamsızlık, ders tekrarı yapmama, dersi anlamak yerine ezberleme, dersi gereksiz bulma, sayısal derse karşı önyargı ve derse katılmamadır. Genel görüş olarak ders devamının başarıyı artıran bir faktör olduğu kuşkusuzdur. Bu görüşü destekleyen çok sayıda çalışma da mevcuttur. Başlıcaları (Baard vd., 2010; Jameel ve Hamdan, 2015; Bostan ve Karakaya, 2016; Feriştah ve Ömer, 2015) gibi sayılabilir. Bunun yanında devamsızlığın ders başarısında önemli olmadığı bulgusu elde etmiş bir çalışmaya da rastlanmıştır (Demir ve Çam, 2006). Muhasebe gibi öğrenimde katılımın çok gerekli olduğu bir ders için devam gereksizliği yönünde elde edilen bu sonuca yazarların hiç yorum yapmamaları eleştiri konusudur.

Dersi anlamak yerine ezberlemeye çalışmak da aslında ders çalışma yönteminin iyi bilinmediğinin ya da konunun anlaşılmadığının bir göstergesidir. Baştürk de (2012), çalışmasında bu durumun başarısızlığa etki ettiğini belirtmiştir.

$\mathrm{Bu}$ çalışmanın bulguları ile paralellik gösteren; derse katılımın, dersi iyi dinlemenin, tekrar yapmanın, sıkı ve disiplinli çalışmanın başarıyı olumlu yönde etkilediğine yönelik çalışmalar da vardır (Dursun ve Dede, 2004; Sugahara ve Boland, 2014). Çalışma bulgularına göre bazı öğrenciler sayısal dersleri gereksiz bulmuşlardır. Buna neden olarak bu öğrencilerin okulun misyonunu, aldıkları eğitimin hedefini, kapsamını ve edinecekleri meslek ile sayısal derslerin ilişkisini tam anlamamış olmaları gösterilebilir. Bernardi ve Bean (2002) çalışmalarında, alınan eğitimle ilgili olan sayısal derslerin faydasını anlamış olmanın derse olan ilgiyi ve öğrenci motivasyonunu yükselttiği; Coşgun (2013) ise yükselen motivasyonun başarıyı olumlu etkilediği sonucuna varmışlardır.

Çalışmamızda elde edilen bulgulardan, öğrencilerin bu bölümdeki sayısal dersleri yüksek düzeyde matematik bilgisi gerektiren dersler olarak gördükleri anlaşılmaktadır. Öğrencilerin orta öğretim sürecinde matematik dersleri ile ilgili yaşadıkları olumsuz tecrübeler, içeriğini bilmeden tüm sayısal derslere karşı endişe duymalarına ve önyargı oluşturmalarına yol açmaktadır. Literatürde de benzer bulgulara sahip çalışmalar mevcuttur. Örneğin Özdemir (2018), aslında ileri düzeyde matematik bilgisi gerektirmeyen muhasebe eğitiminde, başarısız olan öğrencilerin, suçu haksız yere matematik bilgilerindeki eksikliğe yüklediklerini belirtmektedir. Tho (2007) da öğrencilerin kendilerini başarı için yeterli görmelerinin başarıyı olumlu yönde etkilediğini belirlemiştir.

Görüşmelerde elde edilen bulgulara göre derslerin öğretim üyeleri, öğrencilerin sayısal derslerden başarısız olma nedenlerini yalnızca davranışsal nedenlere bağlamışlardır. Öğrencinin belirttiği fiziksel nedenlerin bir kısmının yine öğrencinin ihmalinden kaynaklandığını belirtmişler ve bunları sayısal derslerdeki başarısızlığa gösterilen bahaneler olarak değerlendirmişlerdir. Davranışsal nedenlerin sayısal ders başarısızlığındaki önemi, hem odak gurup görüşmesine katılan öğrenciler hem de moderatör olarak görev yapan ve gözlemlerde bulunan araştırmacı tarafından da desteklenmektedir.

\section{SONUÇ ve ÖNERILLER}

$\mathrm{Bu}$ çalışma turizm öğrencilerinin sayısal derslerdeki başarısızlık nedenlerinin belirlenmesi amacıyla gerçekleştirilmiştir. Çalışmanın bulguları literatürdeki benzer çalışmalarla aynı niteliği taşımaktadır. Üniversite düzeyindeki turizm öğrencileriyle yapılan odak gruplar sonucunda 
başarısızlığa etki eden faktörlerin yine öğrencilerin davranışsal özelliklerinden ve okuldaki fiziksel olanaksızlıklardan kaynaklı olduğu bildirilmiştir.

Turizm Fakültesi'ndeki lisans programında verilen muhasebe, finansman ve maliyet analizi dersleri ileri düzey matematik işlem bilgisi gerektirmemektedir. Bu dersler daha çok öğrenciye, bilimsel yöntemlere ve teorik bilgilere dayanarak, işletmenin sayısal verilerini kaydetme, raporlama, analiz etme, muhakeme etme, yorum yapma ve karar verme becerilerini kazandırmaya yöneliktir. Ancak gerek literatür bilgileri gerekse bu çalışmanın sonuçları, öğrencilerin dersi matematikle bir tuttuklarını göstermektedir. Buradan da öğrencilerin üniversiteye geldiği döneme kadar aldığı matematik derslerindeki başarı veya başarısızlıklarını düşünerek, bu derslere karşı bir önyargı geliştirdikleri anlaşılmaktadır. Turizm öğrencilerinin büyük çoğunluğu turizm meslek lisesi mezunlarıdır. Meslek liselerinde ağırlıklı olarak mesleki uygulama dersleri gördükleri için öğrenciler, matematik konusunda yetersiz olduklarını bilmektedirler. Muhasebe, finansman ve maliyet derslerinin de ileri düzeyde matematik bilgisi gerektireceğini düşünerek, başarısız olacakları önyargısı ile derslere mesafeli yaklaşmaktadırlar. Bunun sonucunda devamsızlık, not tutmamak, düzenli ders çalışmamak ve sınav odaklı ezbere dayalı çalışmak gibi hatalı davranışlar nedeniyle başarısızlığı kendileri getirmektedirler.

Öğrencilerin ifade ettikleri başarısızlık nedenlerinden bir diğeri ise okulun fiziki şartları ve olanaklarıdır. Derslerden bazıları 60 kişilik sınıflarda, bazıları ise bir konferans salonunda yapılmaktadır. Öğrenciler konferans salonunda yapılan derslerde salonun yeterince isınmaması, sesin her yere eşit dağılmaması ve tahta görüş mesafesinin uzak olmasından dolayı başarısız olduklarını ifade etmişlerdir.

Sayısal derslere giren öğretim üyelerinin birçok konuda öğrenciler ile aynı görüşte olmadıkları görülmektedir. Öğretim üyeleri, tahtaya uzak oturan öğrencileri iki gurupta toplamışlardır. İlk guruptakiler; derse ilgisiz olup kendi tercihleri ile arka sırada oturanlar; ikinci guruptakiler ise derse geç kaldıkları için zorunlu olarak arka sıralarda oturmak durumunda kalanlardır. Öğretim üyelerinin ifadelerine göre; bazı derslerde sınıfların kalabalık olmasının nedeni, dersi alttan alan öğrencilerdir. Dolayısıyla tahtaya ve dersin hocasına olan mesafenin uzak oluşunda ve sınıf şartlarının uygun olmayışında direkt ve dolaylı olarak öğrencinin ihmali söz konusudur. Ayrıca, sayısal derslerde başarı elde edebilmek için öğrencilerin uyması gereken; derse devam etme, derste not tutma, derste soru çözme ve dersi anlayarak tekrar etme prensipleri, sıklıkla öğrencilere hatırlatıldığı halde öğrencilerin büyük bir kısmının bu konuda özensiz olduğu gözlenmektedir. Bunun haricinde okuldaki fiziksel koşullar ve olanaklar, öğrenmeye istekli ve dersin şartlarını yerine getiren öğrenciler için bir sorun teşkil etmemektedir.

Elde edilen sonuçlar ışığında, sayısal ders olarak alınan muhasebe - finansman ve maliyet analizi gibi derslerde başarının sağlanması için aşağıdaki öneriler sıralanabilir:

1- Öğrencilere sayısal derslerin amacı, önemi ve turizm işletme yönetimindeki yeri iyi anlatılmalıdır. Bunun için dersin başında ve ara ara öğretim üyesi tarafından açıklamalar yapılabilir. Ayrıca, çeşitli turizm işletmelerinden davet edilen bazı yöneticiler derse konuk edilerek muhasebe - finansman ve maliyet analizi gibi sayısal derslerin işletmeler ve onların yönetimi açısından önemi vurgulanabilir.

2- Sayısal derslere olan ön yargıların ve kaygıların ortadan kalkması için dönemin başından itibaren öğrenciye sık sık ileri düzeyde matematik bilgisine gerek olmadığı hatırlatılabilir ve sınıf içinde yaptırılan kolay ve eğlenceli uygulamalarla derse olan motivasyon sağlanabilir.

3- Sayısal derslerde başarılı olmak için gerekli olan prensipler, dönemin başında çok yoğun bir şekilde anlatılabilir. Bu çalışmadan elde edilen sonuçlar öğrenciye gösterilebilir ve açılanabilir. Bunu daha etkili kılmak için sayısal derslerde başarılı ve başarısız olmuş üst sınıf öğrencilerinden 
yardım alınabilir. Bu öğrenciler derslere davet edilerek derslerdeki prensiplerin önemi ve öğrencilerin yaşadıkları olumlu ve olumsuz tecrübeler vurgulanabilir.

4- Dersi alttan alan öğrencilerden dolayı derslerin kalabalık olması durumunda öğrencileri bölerek ikinci bir sınıfın açılması sağlanabilir. Bunun için dersin öğretim üyesi ve okul yönetiminin birlikte çalışması gerekmektedir. Öğrencilerin sınıfın fiziksel koşullarında gördükleri olumsuz durumlar sadece öğrenci arasında konuşulan bir şikayet konusu olarak kalmamalıdır. Sınıf temsilcisi aracılığı ile sorunlar okul yönetimine bildirilebilir ve çözüm aranması sağlanabilir.

5- Öğrenciler ve sayısal derslerin öğretim üyeleri arasında iyi bir diyalog olması öğrencilerin sayısal derslere olan kaygılarını azaltabilir, cesaretlerini ve motivasyonlarını artırabilir. Bunun için ders haricinde beraberce çeşitli etkinlikler yapılabilir.

$\mathrm{Bu}$ çalışmada, Adnan Menderes Üniversitesi Turizm Fakültesinde lisans düzeyindeki öğrencilerin sayısal derslerde başarısız olma nedenleri kendi açlarından ve öğretim üyeleri açısından ortaya konmaktadır. Çalışma sonuçları, öğrencilerin bu derslere karşı önyargılar ve kaygılar taşıdığını ve bu nedenle başarısızlıkların belli orandaki nedenlerini ilgisi olmayan konulara yüklediklerini göstermektedir. Bu çalışma öğrenciye, sayısal derslerde başarıyı getiren asıl konunun dersin öğrenme prensiplerini benimsemek ve onları disiplinli bir şekilde uygulamak olduğunu anlamalarında ve gereksiz önyargılardan kurtulmalarında rehberlik edecektir. Bunun için çalışmadan elde edilen sayısal dersi öğrenme ve başarılı olma prensipleri, bu alanda eğitim veren kurumlarda, sayısal derslerin başlangıcında öğrencilere aktarılmalı ve belli sıklıklarla da hatırlatılmalıdır.

Sayısal derslerde başarı konusunda bundan önce yapılan araştırmalarda genellikle kullanılan nicel yöntemlerden farklı olarak; bu çalışmada nitel veri kullanılması, konunun farklı bir yönden derinlemesine incelenmesini sağlamış ve bu yönde yapılacak sonraki araştırmalar için bir örnek oluşturmuştur. Çalışmanın sinırlılıkları dikkate alındığında, gelecekte daha büyük örneklem grubu üzerinden nitel ve nicel verilerle karma yöntemli bir çalışma gerçekleştirilerek başarısızlığa etki eden faktörler ve etki dereceleri daha somut bir şekilde ortaya konabilir.

\section{KAYNAKÇA}

Baard, R.S., Steenkamp, L.P., Frick, B.L. and Kidd, M. (2010) Factors influencing success in firstyear Accounting at a South African university: The profile of a successful first year Accounting student, South African, Journal of Accounting Research, 24(1): 129-147.

Başkale, H. (2016). Nitel Araştırmalarda Geçerlik, Güvenirlik ve Örneklem Büyüklügünün Belirlenmesi, Dokuz Eylül Üniversitesi Hemşirelik Fakültesi Elektronik Dergisi, 9(1): 23-28.

Baştürk, S. (2012). Sınıf Öğretmenlerinin Öğrencilerin Matematik Dersindeki Başarı ya da Başarısızlı̆̆ına Atfettikleri Nedenler, Mehmet Akif Ersoy Üniversitesi Sosyal Bilimler Enstitüsü Dergisi, 4(7): 105-118.

Bernardi, R. A. and Bean, D. F. (2002). The Importance of Performance in Intermediate Accounting I on Performance in a Subsequent Accounting Course, Accountin Educators' Journal, 14: $1-13$.

Bostan, A. ve Karakaya, Ö. (2016). Öğrenci Ders Devamının Sınavlarda Alınan Notlara Etkisi Üzerine Bir Durum Çalışması, Mersin Üniversitesi Eğitim Fakültesi Dergisi, 12(1): 211-222.

Coşgun, N. (2013). Muhasebe Eğitimi Alan Öğrencilerin Motivasyonlarının ve Beklentilerinin Değerlendirilmesi: Çanakkale Onsekiz Mart Üniversitesine Bă̆ll Meslek Yüksekokullarında Bir Uygulama, Yayımlanmamış Yüksek Lisans Tezi, Çanakkale Üniversitesi, Çanakkale. 
Çokluk, Ö., Yılmaz, K. ve Oğuz, E. (2011). Nitel Bir Görüşme Yöntemi: Odak Grup Görüşmesi, Kuramsal Eğitimbilim, 4(1): 95-107.

Demir, M. ve Çam, M. (2006). Muhasebe Bölümü Öğrencilerinin Muhasebe Öğreniminde Başarılarını Olumsuz Etkileyen Faktörlere İlişkin Bir Araştırma, Muhasebe ve Finansman Dergisi, 32: $1-11$

Dursun, Ş. ve Dede Y. (2004). Öğrencilerin Matematikte Başarısını Etkileyen Faktörler: Matematik Öğretmenlerinin Görüşleri Bakımından, Gazi Üniversitesi Gazi Eğitim Fakültesi Dergisi, 24(2): 217230.

Echtner, C.M. and Jamal, T.B. (1997). The Disciplinary Dilemma of Tourism Studies, Annals of Tourism Research, 24(4): 868-883.

Erlandson, D. A., Harris, E. L., Skipper, B. L. and Allen, S. T. (1993). Doing Naturalistic Inquiry: A Guide to Methods. Beverly Hills, CA: Sage.

Erol, M. ve Erkan, G. (2008). Lisans Düzeyinde Muhasebe Eğitim, Alan Öğrencilerin Başarılarını Etkileyen Faktörlerin Belirlenmesine Yönelik Biga İktisadi ve İdari Bilimler Fakültesinde Bir Araştırma, Karamanoğlu Mehmet Bey Üniversitesi İ̈BF Dergisi, 8(14): 1-18.

Feriştah, D. ve Ömer, A. (2015). Öğrenci Devamsızlıklarının Akademik Başarı Üzerindeki Etkisi. [Online] https://prezi.com/zhvyovaap9kj/ogrenci-devamsizliklarinin-akademik-basariuzerindeki-etkisi/ [Erişim: 02.05.2020].

Gülleroğlu, H. D. (2005). Üniversite Öğrencilerinin Akademik Başarılarının Yordanmasına İlişkin Karşılaştırmalı Bir Araştırma, Yayımlanmamış Doktora Tezi, Ankara Üniversitesi, Ankara.

Holloway, I., and Wheeler, S. (1996). Qualitative research for nurses. Oxford: Blackwell Science Ltd.

İlhan, M. ve Sünkür, M. Ö. (2013). Matematik Kaygısının Matematik Başarısını Yordama Gücünün Cinsiyet ve Sınıf Değişkenleri Açısından İncelenmesi, Gaziantep Üniversitesi Sosyal Bilimler Dergisi, 12(3): 427-441.

Jameel, S. H. and Hamdan, A. (2015). Effects of Student's Attendance on Accounting Student's Performance, International Journal of Business and Management Review, 3(5): 79-93.

Karcıoğlu, R., Ağırman, E. ve Özcan, M. (2016). Ön Lisans ve Lisans Düzeyinde Muhasebe Eğitimi Alan Öğrencilerin Başarılarına Etki Eden Faktörler: Atatürk Üniversitesi Açık Öğretim Fakültesi Üzerine Bir Araştırma, Atatürk Üniversitesi Sosyal Bilimler Enstitüsü Dergisi, 20(4): 15351548.

Karcioğlu, R., Bilsen, B. ve Yazarkan, H. (2010). Muhasebe Yüksek Öğrenimi Gören Öğrencilerin Kişilik Özellikleri ve Mesleğe Yönelik Düşünceleri Üzerine Bir Alan Araştırması, Muhasebe ve Denetime Bakış Dergisi, 10: 1-15.

Karesioğlu, F. ve Duman, H. (2011). Meslek Yüksekokullarında Muhasebe Eğitimi ve Kalitesi Üzerine Bir Not, Gaziantep Üniversitesi Sosyal Bilimler Dergisi, 10(1): 165-180.

Koh, M. Y. and Koh, H. C. (1999). The Determinants of Performance in an Accountancy Degree Programme, Accounting Education, 8(1): 13-29.

Kuşat, N. (2014). Meslek Yüksekokullarında Öğrenci Başarısı Üzerine Bir Çalışma: Eğirdir Meslek Yüksekokulu Muhasebe Programı Örneği, Muhasebe ve Finansman Dergisi, 61(1): 65-79.

Mil, B. (2007). Görüşme Tekniği, (Editörler) Yüksel, A., Mil, B. ve Bilim, Y.: Nitel Araştırma: Neden, Nasıl, Niçin? içinde (ss.3-26) Ankara: Detay Yayıncılık.

Morgan, D.L. (1997). Focus Groups as Qualitative Research. California: SAGE. 
Mumcu, H. Y., Mumcu, İ. ve Aktaş, M. C. (2012). Meslek Lisesi Öğrencileri İçin Matematik, Amasya Üniversitesi Ĕ̆itim Fakültesi Dergisi, 1(2): 180-195.

Olcay, A. (2008). Türk Turizminde Eğitimin Önemi, Gaziantep Üniversitesi Sosyal Bilimler Dergisi, 7(2): 383-390.

Onwuegbuzie, A. J. and Leech, N.L. (2007). A Call for qualitative power analyses, Quality $\&$ Quantity, 41: 105-121.

Özdemir, F. S., Bulut, E. ve Ünal, İ. H. (2018). Muhasebe Dersi Alan Öğrencilerin Matematiğe Bakış Açısı ve Akademik Başarıları, Ömer Halisdemir Üniversitesi İktisadi ve İdari Bilimler Fakültesi Dergisi, 11(4): 143-161.

Suguhara, S. and Boland, G. (2014). How Accounting Students Define Success, and the Factors Affecting Their Success and Failure, While Studying in The Accounting Schools Of Japan, Procedia Social and Behavioral Sciences, 141: 64-69.

Tho, L. M. (2007). Self-Efficacy and Student Performance in An Accounting Course, Journal of Financial Reporting \& Accounting, 4(1): 129-146.

Thomson, S., Lokan, J., Lamb S. and Ainley, J. (2003). Lessons from The Third International Mathematics and Science Study, Australian Council for Educational Research.

Türnüklü, A. (2000). Eğitimbilim Araştırmalarında Etkin Olarak Kullanılabilecek Nitel Bir Araştırma Tekniği: Görüşme, Kuram ve Uygulamada Ĕ̆itim Yönetimi, Güz (24): 543-559.

Yıldırım, A. ve Şimşek, H. (2013). Sosyal Bilimlerde Nitel Araştırma Yöntemleri. (9. Baskı), Ankara: Seçkin Yayıncılık. 